\title{
Spatial Analysis of the Implications of Traffic and Parking Activities in the Mubi Cattle Market Area, Adamawa State, Nigeria
}

\author{
Phanuel B. JOSHUA', John O. ODIHI' \\ ${ }^{1}$ University of Maiduguri, Faculty of Social Sciences, Department of Geography, Maiduguri, Borno State, NIGERIA \\ E-mail: phanijokadafa@gmail.com, odihi@fass.ubd.edu.bn
}

DOI: 10.24193/JSSP.2018.1.07

https://doi.org/10.24193/JSSP.2018.1.07

K e y w o r d s: Mubi cattle market, traffic, parking, survey, cordon points, planning

\begin{abstract}
A B S T RA C T
Traffic studies have been a paramount aspect of proper transportation planning in every urban area in any part of the world, including Nigeria. This paper seeks to analyze the traffic and parking situation related to the Mubi cattle market area in order to make some planning recommendations. Data for the study was generated through a traffic survey and counting of vehicles at three cordons points namely Ahmadu Bello Way, Cattle Market Road junction and along Maiha Road, on a quarterly basis. Similarly, a parking survey was also conducted at hourly intervals within the cattle market and on the roadsides in front of the cattle market. Surveys were conducted on the pre-market day (Monday), on the market day (Tuesday) and on the post-market day (Wednesday) to compare traffic volume and parking variations. Results show that traffic volume increased in the evening compared to the morning of the market day (Tuesday), and became lower on Wednesday. Pre-market day survey showed lower traffic than Tuesdays and Wednesdays. However, Wednesday evenings recorded higher traffic than in the mornings because the loading of cattle coincides with other vehicles returning home after work during the rush-hour. Considering all traffic and parking challenges, the road network around the area should be redeveloped to handle traffic, while the cattle market should be relocated away from the population hub to the outskirts of the town to overcome the traffic bottlenecks around the present market.
\end{abstract}

\section{INTRODUCTION}

Mubi Cattle Market is located within the town of Mubi, Adamawa State, Nigeria. The weekly market that is held every Tuesday and it is a revenue spinner for the commercial town has also become a source of a significant traffic congestion problem in the town [1]. This market attracts customers from the state, other parts of the country, as well as across international borders (Cameroon, Chad and Central Africa Republic). Similarly, the improved transportation system has helped increase the tempo of marketing operations [2] which further adds to the traffic situation. The marketrelated traffic, which may be over 10 times its normal volume (that is, non-market day), creates a nightmarish traffic experience for the Mubi town residents. Against this background, the present study was elaborated to yield the Cattle market related facts that may guide actions to mitigate traffic problems in the town. Traffic counting methods and transport planning at all levels requires understanding of actual conditions for proper land use planning. This involves the determination of vehicle or pedestrian numbers, vehicle types, vehicle speeds, vehicle weights, as well as more substantial information such as trip length, purpose and frequency. The first group of data, dealing with the characteristics of vehicle or people movement, was obtained by undertaking traffic counts [3]. 
Traffic volume studies were conducted to determine the number, movements, and classifications of roadway vehicles at a given location. This data can help us identify critical flow time periods, determine the influence of large vehicles or pedestrians on vehicular traffic flow, or document traffic volume trends. Land use and transportation have broad areas of overlap and are closely interwoven. Urban areas in their present form would be impossible to function without facilities for the extensive movement of people and goods [4].

The situation in Europe, especially in London livestock markets, indicated that the development of road network of trunk routes and in the last 50 years or so has replaced the railway system, which influenced livestock markets in the past [5].

The choice of location of any market is a key decision, particularly for urban wholesale markets. The question of location is closely bound up with that of transport, as markets are essentially the only transit stops. Transportation changes and evolving road networks will significantly influence whether it is still viable for a market to remain in its present location or whether a new site should be sought [6].

The location of markets in close proximity to residential areas has encouraged frontage shops development, shopping streets and hawking activities. Consequently, it brings about planning implications in terms of congestion and/or activity density which creates bottlenecks and traffic management problems in the vicinity of the market. Markets are also described as "magnets" or landmarks of great economic, social and political influence [7].

One of the solutions adopted in England in recent years is the movement of some livestock markets from traditional town centres sites to the edge of town; for example, Cirencester livestock market [5].

This paper focuses on the analysis of traffic volume and parking situation in and around the Mubi cattle market due to its present location with a view to proposing a relocation of the market to a suitable location for more functional urban system of Mubi town.

\subsection{Aim and objectives of the study}

The aim of the study is to analyze the traffic situation at the Mubi cattle market and its environs with a view to suggesting actions that will ameliorate the present traffic problems in the town. This will be achieved through the following objectives:

- determine the ways cattle market related activities cause traffic problems in Mubi;

- determine the proportion of vehicles parked at various locations around the cattle market;

- compare the parking situations at different times of the day;

- assess the demand for parking space(s);
- examine the volume of traffic at different cordon points around the cattle market;

- compare the variations of traffic volume at different location (cordon points);

- suggest ways to mitigate the cattle market related traffic problems.

\subsection{The study area}

Mubi town is located between Latitude $10^{\circ} 16^{\prime} 8$ ' $\mathrm{N}$ and $10^{\circ} 20^{\prime} 00$ ' $\mathrm{N}$ as well between Longitude $13^{\circ} 16^{\prime} 14$ "E and $13^{\circ} 20^{\prime}$ 'Oo" E. It has a population of 225,721 [8] and has a total land area of $25 \mathrm{~km}^{2}(2,500$ hectares) including the floodable areas, rivers, and streams [9]. Figure 1 describes the location of Mubi in Adamawa State and at national level (Nigeria) as well as the international cattle routes. Similarly, figure 2 shows a portion of Mubi urban area limit in relation to the current cattle market and the location of the proposed one.

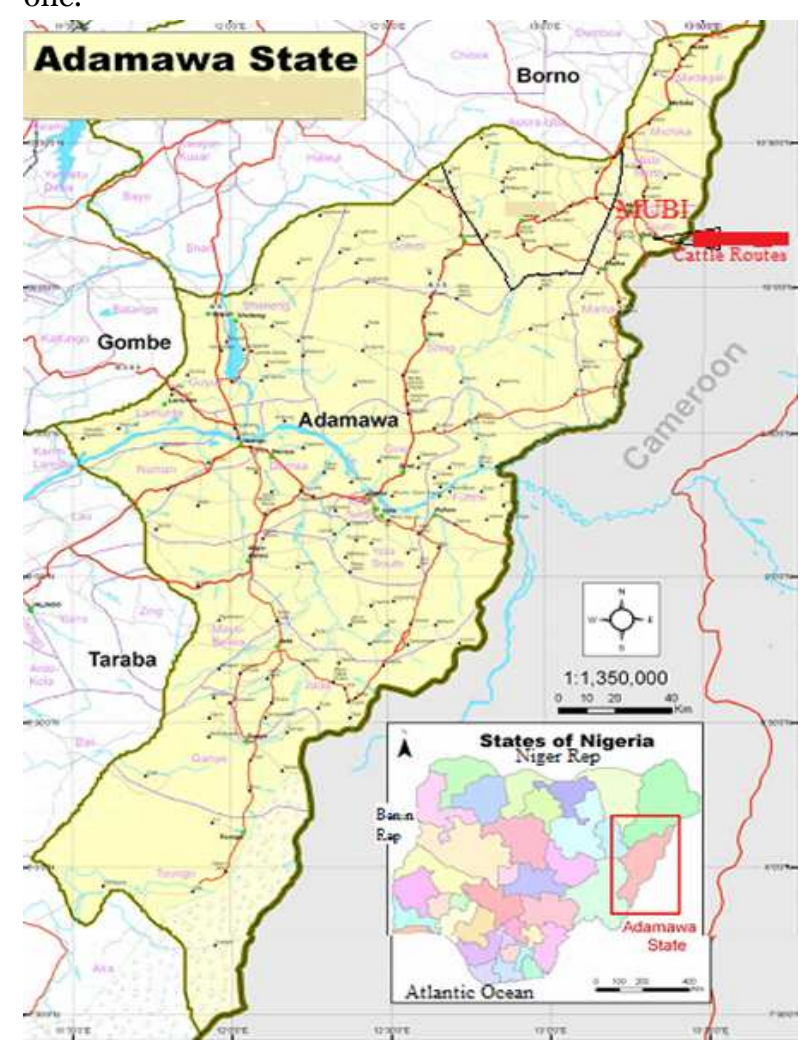

Fig. 1. Adamawa State, Nigeria (showing location of Mubi and Cattle routes). Source: [22] with modifications.

Mubi is a commercial town owing to its location on the border, many individuals from Nigeria and the neighbouring countries namely Cameroon, Chad, and Central Africa coming to make purchases in Mubi market and the cattle market, as well [10]. The people of Mubi are predominantly Fali and Gude and Fulani tribes as well as Hausa, Higgi, and Marghi people among others tribes from neighbouring settlements [11]. The Fali and Gude people are mostly farmers, while the Fulanis are cattle rearers. 


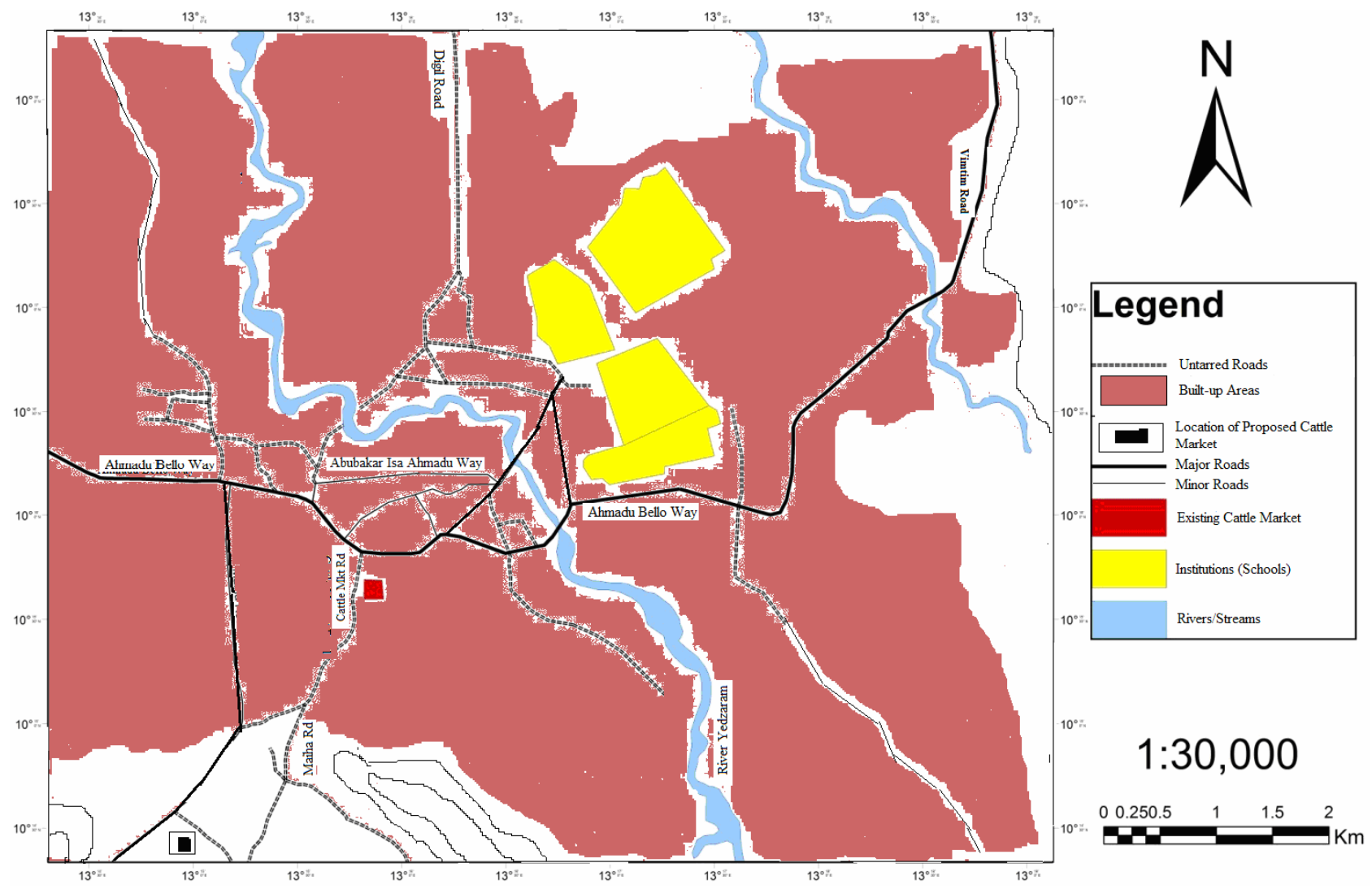

Fig. 2. Mubi township showing locations of the existing and proposed Cattle Market (source: Surveying Dept., FUT, Yola).

\section{METHODS AND MATERIALS}

Traffic and parking survey around the cattle market on the market day was carried out with the help of assistant researchers, who are educated and are familiar with traffic and parking surveys. It was conducted to support the following traffic analysis of the cattle market area. Cordon points were delineated on Ahmadu Bello Way, cattle market road junction and on the road approaching the market from the south side (Maiha Road). This involved the counting of vehicles passing along the cattle market road and Ahmadu Bello Way over a certain period of time. Slack (2013) defined this method as non-intrusive [3] while there are also intrusive methods, which are automated in nature and are widely used in Europe and the United States. However, a more efficient automated system known as Road Transport and Traffic Telematics (RTTT) is widely used in Europe now for traffic surveys [12]. Since these automated systems were not readily available during this study, a rudimentary manual counting method was used.

The volume of traffic movement at different times of the day, the type of vehicle, duration of parking and location were presented spatially. The roadside counting of vehicles along the cattle market road and Ahmadu Bello Way was carried out to determine the number of vehicles trip origin and destination. Also, a parking survey, involving the counting of parked vehicles, types and duration of parking at the cattle market area was carried out.

The traffic surveys were carried out on Mondays (pre-market day), Tuesdays (market day) and Wednesdays (post-market day) so as to provide information on variations in the traffic volume related to the spatial activity of cattle marketing and transportation. This pattern was adopted through the subsequent surveys conducted on quarterly basis (3 months interval). Therefore three surveys were conducted at specific cordon points around the cattle market.

\section{FINDINGS AND DISCUSSION}

Transportation planning of every urban centre requires adequate traffic data (volume of traffic and parking situation) so as to ensure smooth mobility within the urban system. The location of a market directly influences the location of other commercial facilities in a town or city and is therefore central to the performance and prospects of the town or city itself [7], [13].

For example, the siting of the Mubi cattle market where it is today has attracted the development of commercial and residential land uses. These land uses and transportation have a mutually reinforcing 
relationship. The land uses attract transportation activities and the existence of transportation stimulates land use and services infrastructure. The location of the Mubi cattle market has attracted various transportation activities of conveying people, cattle, and other goods and services. The observed problems associated with the location of the Mubi cattle market include traffic congestion, parking space shortage, environmental pollution, noise and inadequate land for infrastructure development.

Findings show that with urban growth and the need to improve public health standards, the Mubi Master Plan recommended that the cattle market be moved to the west of the town on the proposed Northern realignment of the main East-West road (Ahmadu Bello Way).

\subsection{Traffic congestion problem}

The survey shows that the location of the Mubi cattle market has triggered serious traffic management bottlenecks in and around the cattle market area especially during the peak hour on Tuesdays being the market day. This situation is similar to what is obtainable in Maigatari Cattle market in Jigawa State (Nigeria) where inadequate space has brought about traffic and accidents problems [14]. The first traffic survey revealed in Fig. 3 clearly indicates that highest traffic is recorded on Tuesdays, which is the market day along the cattle market road both in the mornings and evenings. However, the situation is at its lowest on Mondays compared to Wednesdays.

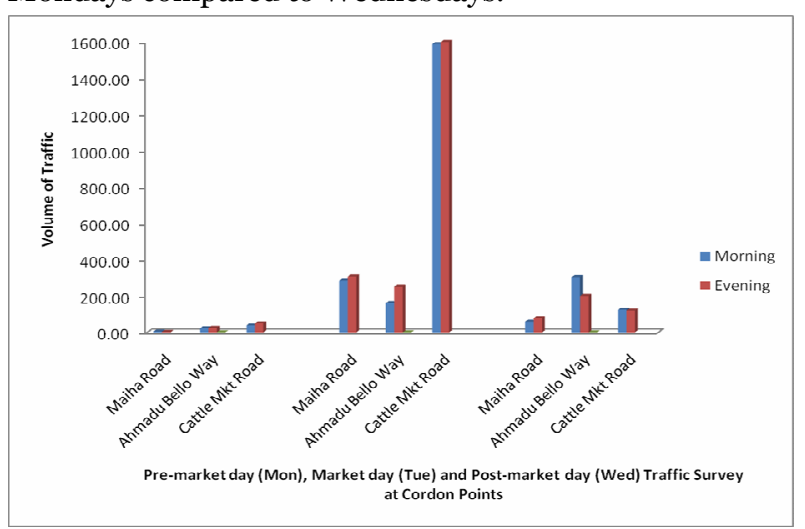

Fig. 3. Traffic survey 1 - results on Monday, Tuesday and Wednesday (mornings and evenings).

Table 1. Traffic survey 2.

\begin{tabular}{|l|rrrrrrrr}
\multicolumn{1}{c|}{ Cordon Points } & \multicolumn{3}{c}{ Traffic (morning) } & \multicolumn{4}{c|}{ Traffic (evening) } \\
& M & \multicolumn{1}{c|}{ T } & \multicolumn{1}{c}{ W } & \multicolumn{1}{c|}{ TL } & M & \multicolumn{1}{c|}{ T } & W & TL \\
\hline Cattle Mkt Road & 161 & 1499 & 547 & 2207 & 211 & 1401 & 467 & 2079 \\
Share (\%) & 7.3 & 67.9 & 24.8 & 100 & 10.1 & 67.4 & 22.5 & 100 \\
Maiha Road & 100 & 350 & 439 & 889 & 89 & 405 & 426 & 920 \\
Share (\%) & 11.2 & 39.4 & 49.4 & 100 & 9.7 & 44.0 & 46.3 & 100 \\
Ahmadu Bello Way & 199 & 250 & 110 & 559 & 222 & 187 & 118 & 527 \\
Share (\%) & 35.6 & 44.7 & 19.7 & 100 & 42.1 & 35.5 & 22.4 & 100
\end{tabular}

Table 2. Traffic survey 3 .

\begin{tabular}{l|rrrrrrrr}
\multicolumn{1}{c|}{ Cordon Points } & \multicolumn{4}{c}{ Traffic (morning) } & \multicolumn{4}{c}{ Traffic (evening) } \\
& \multicolumn{1}{c|}{ M } & \multicolumn{1}{c}{ T } & \multicolumn{1}{c}{ W } & \multicolumn{1}{c}{ TL } & M & \multicolumn{1}{c}{ T } & W & TL \\
\hline Cattle Mkt Road & 123 & 1780 & 487 & 2390 & 222 & 1501 & 482 & 2205 \\
Share (\%) & 5.1 & 74.5 & 20.4 & 100 & 10.1 & 68.0 & 21.9 & 100 \\
Maiha Road & 167 & 380 & 334 & 881 & 165 & 241 & 232 & 638 \\
Share (\%) & 19.0 & 43.1 & 37.9 & 100 & 25.9 & 37.8 & 36.3 & 100 \\
Ahmadu Bello Way & 211 & 212 & 222 & 645 & 200 & 199 & 221 & 620 \\
Share (\%) & 32.7 & 32.9 & 34.4 & 100 & 32.3 & 32.1 & 35.6 & 100
\end{tabular}

This is so because there is only one road leading into the market area; there is no by-pass. While it may be adequate for the normal and non-market days, it is too narrow for the volume of traffic using the road on the market day. The road is about 3.5 metres wide and cannot accommodate two large vehicles side by side at a time thereby making it difficult for such vehicles to drive around with ease without causing traffic congestion and sometimes even accidents. Cattle bought in the market are destined for distant destinations. The traffic situation on the cattle market day of Tuesdays is so chaotic that some vehicles have to reverse out of the cattle market road to Ahmadu Bello Way due to lack of space to make a U-turn. The high volume of traffic causes traffic gridlock/jam in the area. The frustration with such traffic condition leads to conflicts and accidents among users. Even smaller vehicles such as cars and buses have to park to the curb side to make way for another vehicle to go in or out of the market area. High traffic volume or flows are 
recorded in the mornings and evenings because of the pattern of movements, from their origin to their destination and vice versa. The second traffic survey conducted revealed that highest traffic volume is generated in the evenings of the Tuesdays (market day) and the peak hour when people will be rushing back home (Table 1) which coincides with the time the trailer/trucks are moving out of the cattle market after on-loading for onward transportation to the southern states of Nigeria. A total of 2,207 and 2,079 vehicles in the mornings and evenings respectively on the cattle market road for the three days surveys conducted. This is in contrast to what it is obtained along Maiha road and Ahmadu Bello Way where a total of 889 and 559 vehicles were recorded in the mornings against a total of 920 and 527 vehicles recorded in the evenings for the three days survey. The information is better explained in Table 1.

Table 2 describes the volume of traffic obtained during the third survey at three-month intervals each, when a higher volume of traffic was recorded also on Tuesdays. For instance, 1,780 and 1,501 vehicles were recorded on Tuesday morning and evening respectively along the cattle market road, which further supports the idea that heavy traffic on this road on market days causes a serious gridlock in the area, which has effect on time. There is however fewer traffic on Maiha road and Ahmadu Bello way (details in Table 2). On special occasions, such as Christmas and Sallah, the volume of cattle trade and traffic increases significantly because of the forces of demand and supply associated with the festivities [1].

The traffic surveys also show that the volume of traffic is lower on Wednesdays; but, the evening traffic is equally higher than the one recorded in the morning, just like on Tuesdays. The reason for this is that it coincides with rush-hour when people are on their way back home and the trailer trucks are also leaving the market with cattle loads for onward movement to the Nigerian southern states.

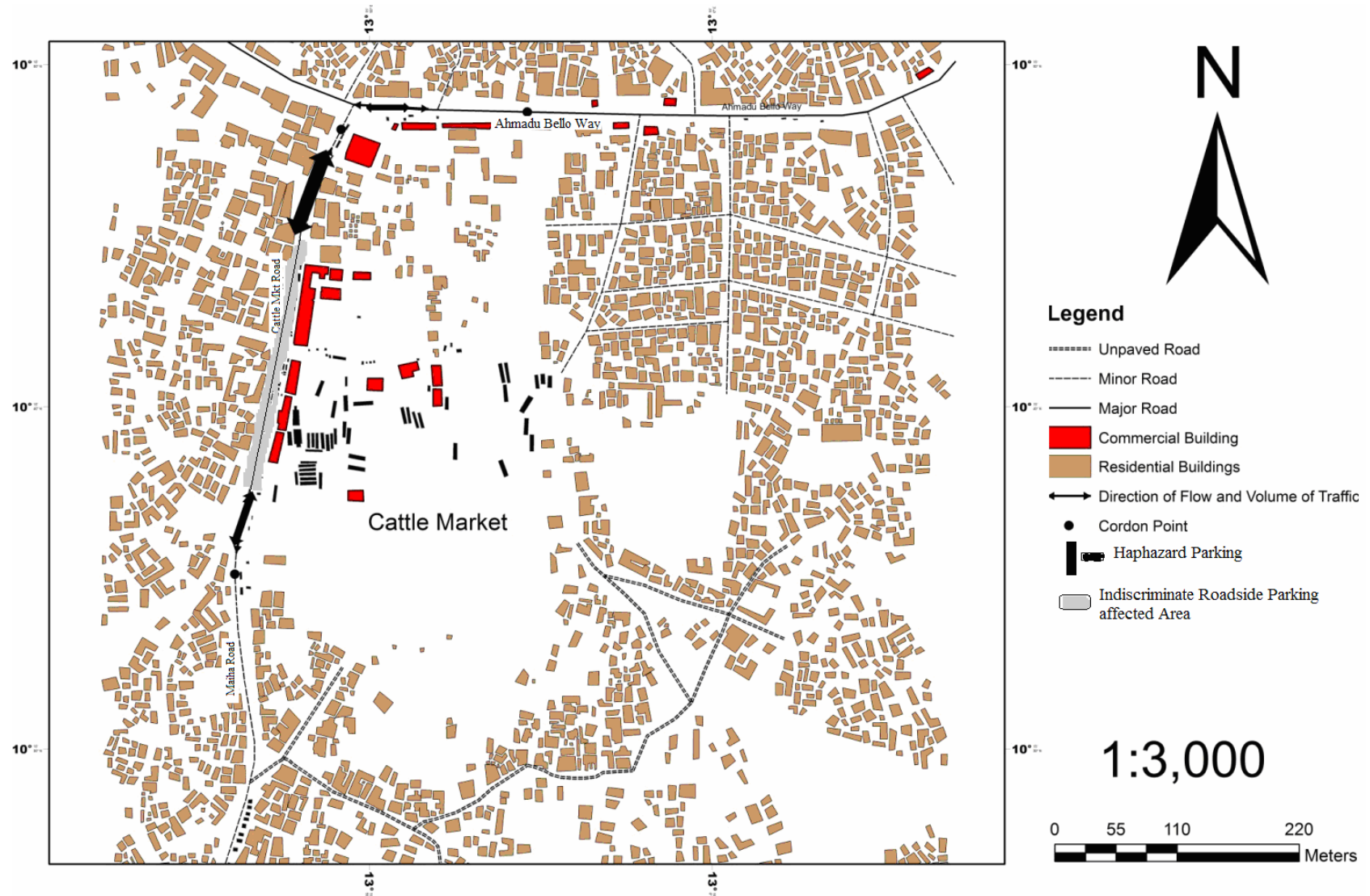

Fig. 4. Traffic/Parking situation at the Mubi Cattle Market (source: Surveying Dept, FUT, Yola).

\subsection{Parking problem}

When well-planned, a market is supposed to have adequate size to be able to accommodate a range of facilities and an adequate parking space. The Mubi cattle market is currently facing the problem of inadequate parking space for both large and small vehicles coming to it. On average, about 40 trailer/trucks come to the market. The available spaces for trailer/trucks can only accommodate a maximum of 25 trailers/trucks. Thus, many of them are forced to park on the roadside of the cattle market road, thereby creating more traffic problems in the area. The pick-up vans are also faced with the same parking dilemma as the available parking space can only accommodate a maximum of 30 pick-up vans at a time, which automatically forces majority of them to look for any other available space outside the market by the roadside 
Table 3. Parking survey over carried out hourly.

\begin{tabular}{|c|c|c|c|}
\hline $\begin{array}{l}\text { Location \& } \\
\quad \text { Time }\end{array}$ & $\begin{array}{c}\text { Number of parked vehicles inside } \\
\text { cattle market }\end{array}$ & $\begin{array}{c}\text { Number of vehicles parked on market } \\
\text { roadside (front) }\end{array}$ & Remark(s) \\
\hline 8 a.m. & 30 & 19 & \\
\hline 9 a.m. & 32 & 21 & \\
\hline 10 a.m. & 32 & 23 & \\
\hline 11 a.m. & 29 & 27 & \\
\hline 12 noon & $55^{*}$ & 19 & *Peak parking inside market \\
\hline 1 p.m. & 45 & 20 & \\
\hline 2 p.m. & 45 & 22 & \\
\hline 3 p.m. & 46 & $30^{* *}$ & **Peak parking on market roadside \\
\hline 4 p.m. & 52 & 25 & \\
\hline 5 p.m. & 30 & 19 & \\
\hline 6 p.m. & 26 & 4 & \\
\hline
\end{tabular}

A gully which affects a large portion of the market, and rock outcrops within the market area pose problems of both space and driving because of the unsuitable terrain [15].

The parking spaces available for the trailer/trucks as well as that of pick-up vans are not delineated, so drivers park their vehicles without due regard for other users. The lack of marked parking space has made it difficult to know where each category of vehicle should park and to enforce proper parking, or penalize parking offenders. Owing to the inadequacy of space in the cattle market, most trailer/trucks are parked somewhere before it is their turn load in the evenings of Tuesday or Wednesday morning, when traffic is lighter in the streets and parking spaces are more available. Parking survey (accumulation count) was conducted inside the cattle market and in front of the market on the cattle market roadside where other vehicles are forced to park for shortage of space.

The result shows that between 26 and 55 vehicles (trucks, pick-up vans, buses, and cars) park inside the cattle market area from 8 a.m. to 6 p.m., while 4 to 30 vehicles park on the roadside of the cattle market road at different times between 8 a.m. and 6 p.m. The peak of parking inside the cattle market is at noon (12 o'clock), while outside by the roadside of the cattle market road the peak of parking is at 3 p.m. The results of the parking survey and spatial characteristics are presented in table 3 and fig. 4 .

\subsection{Implication of the study for urban development}

The significance of traffic analysis or study for any urban development cannot be overemphasized as it gives an insight as to what it obtains at the moment and what should be expected in the future. Traffic will continue to increase as long as human activities thrive in space and time. The pre-market survey (Monday) indicates low traffic, while the traffic registered on Tuesday (Market day) is very high and with very little decrease in the number of vehicles on Wednesday (the post-market day). The increased traffic in and around the cattle market area means that planning is needed for more proper circulation. The current traffic situation at the Mubi cattle market calls for a drastic planning solution to reduce the problem of shortage of parking space for the various transporters and vehicle owners who patronise the market one way or the other.

Studies must be conducted to collect the required information about the capacity and use of existing parking facilities. In addition, information about the demand for parking is needed. Parking studies may be restricted to a particular traffic producer or attractor, such as a store, or they may encompass an entire region, such as a Central Business District (CBD) [16].

In the case of the Mubi cattle market, the attractor is the market and the traffic originates from the southern states of Nigeria and some surrounding communities who also patronize the market. For an urban centre like Mubi, there is the need to have more open space to expand the cattle market and its facilities, especially the parking spaces and surrounding circulation or access roads for a more functional market and urban system, which is not possible in its current location. An alternative location with adequate space will be preferable, similar to the new and the largest cattle market in Ghana, which is located in a suburb of Tamale on a 10-acre land with ranches and loading bays, convenience (toilets), security post and access roads among others [17].

Similar cattle markets with suburb locations are found in Kenya, Ethiopia and UK [18], [19]. Providing bulking sites at the fringes of urban areas for livestock is very important before they are transported to the major markets [20]. Urban growth in the direction of these cattle markets can be controlled for a 
sustainable urban development. The implication of locating a cattle market away from the built-up area is that it allows for traffic flow, while other accidents associated with it are avoided. A functional urban system ensures sustainable urban development; this is the vision for Mubi town.

When cattle markets are located away from the town, growth or expansion in the direction of the cattle market can be controlled through policies and planning legislations to forestall any future chaos with encroaching land uses especially residential land uses [19], [20].

\section{RECOMMENDATIONS}

A market in every urban system requires proper planning with adequate facilities such as parking facilities. Traffic management within an urban area requires proper circulation/access/roads especially around commercial land uses such as a market. The following are therefore recommended:

a). The cattle market should be relocated to accommodate a wide range of facilities including parking spaces and access roads. This would be preferable on the outskirts of the town.

b). The present cattle market should be given another use by the local council. This should involve public participation in the decision-making process so as to achieve sustainable urban environment.

c). Improving the road junction and general circulation around the present cattle market is a paramount to reduce the traffic bottlenecks experience for the residents and the future urban welfare of the area.

d). A by-pass road should be constructed for cross-through traffic; especially for those in transit, who do not need to pass through the market area, so as to reduce the volume of traffic in the area.

e). The Mubi Master Plan has recommended the relocation, while some cattle market stakeholders (transporters, shop owners and cattle dealers) expressed their interest in favour of the relocation [15]. The study indicated that $90 \%$ of the transporters, $60 \%$ of the shop operators and $70 \%$ of the cattle dealers want the cattle market relocated for inadequate space and spatial problems observed. Also, there will be ease of movement for cattle sellers and transporters and costs will be reduced when the cattle market is relocated to the outskirt of the town on less-expensive land. If this option is chosen, the implementation of the proposed plan will succeed considering the all-inclusiveness and general acceptance.

\section{PROPOSALS}

The Mubi cattle market needs to be relocated and well planned so as to have a sustainable cattle market environment. Planning proposal for a new and relocated cattle market in Mubi is required and this has been part of the objectives of this research.

The new proposed Mubi cattle market is expected to have a range of market facilities such as cattle holding facility, slaughterhouse, veterinary clinic, police post, bank, spacious parking area for large and small vehicles, cattle auctioning area, loading and off loading bay, among others. Utility services such as water supply, electricity, and sanitary facilities like toilets will be part of the proposal besides revenue office, administrative building and shops (see Fig. 5).

Theoretical Framework for the Proposal. The new location of the cattle market will be kept clear of the built up area of Mubi town so as to avoid movement of animals in the human settlement. The theoretical basis for the relocation and the choice of site for the new cattle market is rooted in Johann Heinrich Von Thunen's "Isolated states" model. This model can be applied where animal husbandry activities, forestry and grazing activities are kept clear of the city centre [21].

Location of the site. The proposed Mubi cattle market will be located along Mubi-Maiha road, south of Mubi town. It will make a very good location because of the expanse of flat land and the need to keep the cattle from moving through the town as most of the cattle brought from the neighbouring countries of Chad, Cameroon and Central Africa Republic (they are brought by trekking along this road to the cattle market). The justification for this choice is born out of the need to protect the public from dangers created by these large animals when they trek through the town to the cattle market.

Alternative site. The public participatory nature of this planning proposal gave the various stakeholders of the cattle market to make choices as to where they would prefer the market relocated; their choices were diverse and most of them made two choices, namely the area along Maiha-Mubi road and the area along Mubi-Yola road. Most of the stakeholders chose the Mubi-Maiha road because of the existence of available land in that part of the Mubi town.

\subsection{Site analysis of the proposed project}

A basemap was used to identify the nature of the selected site for the proposed project (cattle market). Site analysis of the soil, physiography, vegetation, and hydrology was carried out.

Size and physiographic condition of the site the site of the proposed cattle market, which is situated east of the Mubi- Maiha road, is about 12.70 hectares and the land is relatively flat.

Soil - the soil condition of the selected site reveals good loamy and sandy loam soils. It is well drained and it is suitable for a project such as a cattle market. 


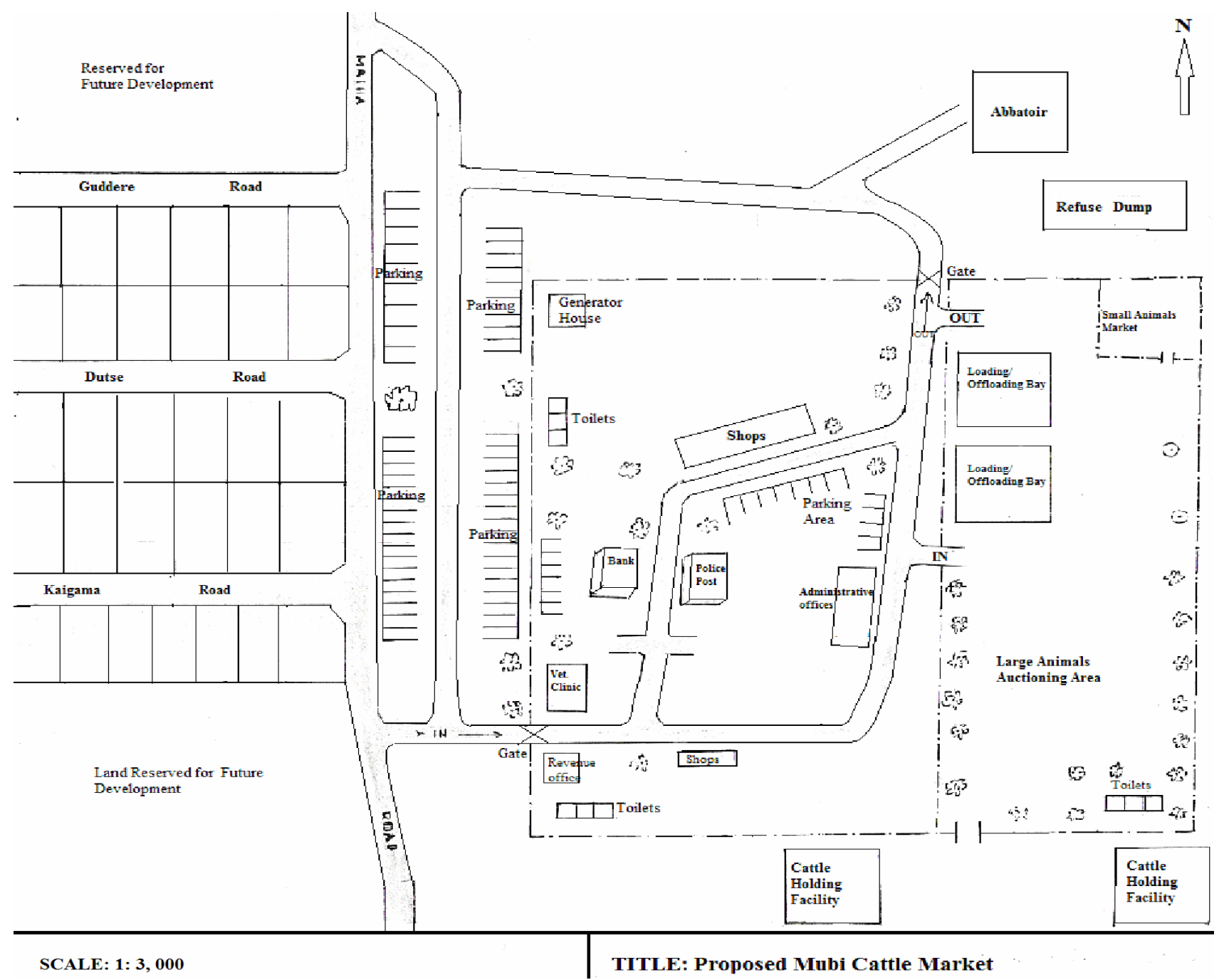

Fig. 5. Proposed Mubi Cattle Market.

Vegetation - the vegetation of the proposed site is the grass woodland with trees such as tamarind, sheabutter, locust bean, and baobab.

Hydrology - the selected site is a well-drained land but there is a need for good drains in and around the proposed cattle market in order to forestall future occurrences of gullies. This is necessary because of the presence of a hill east of the proposed site.

Accessibility - the existing Mubi-Maiha road will serve as the main road from which other access roads will be opened. The proposed cattle market will have as many access roads to ensure proper traffic flow in and around it. It is included in the proposed cattle market plan (see Fig. 5).

Land use - there are other proposed land uses, such as agricultural and residential, on the opposite side of the proposed cattle market.

Land tenure - the site set aside for the proposed cattle market belongs to individual farmers and the people of the area; hence compensation from the government is needed for the land that is to be used for the project.
Project contents and standards. The site plan will give attention to proper location of market facilities to ensure compatibility. Proper orientation of structure will be ensured. The design will incorporate both modern and traditional market facilities, such as the traditional open space, cattle auctioning area, and a modern cattle holding facility. A range of cattle market facilities are discussed below.

Veterinary clinic - there will be a befitting veterinary clinic in the cattle market to provide vaccines for animals and for treatment of diseases noticed in the animals brought to the cattle market. The veterinary clinic is expected to occupy an area of $600 \mathrm{~m}^{2}$.

Administrative building - an administrative block building is required for general administration purposes. The building will contain the offices of the Sarkin kasuwa (Officer-in-charge of the market) from the emirate council; NURTW cattle market chairman, and revenue officers from Mubi South local council and from the States Board of internal revenue, among others. An area of $1000 \mathrm{~m}^{2}$ is set-aside for this purpose. 


\section{Spatial Analysis of the Implications of Traffic and Parking Activities in the Mubi Cattle Market Area, Adamawa State, Nigeria \\ Journal Settlements and Spatial Planning, vol. 9, no. 1 (2018) 67-76}

Banking facilities - the bank building will be for the banks representatives that will come from the various banks in Mubi town to attend the financial needs of their customers; the building will cover an area of $600 \mathrm{~m}^{2}$.

Police office - the need for security of lives and properties in a place such as a cattle market cannot be overemphasized. The police post building will house the security personnel for safety of lives and properties of cattle owners and buyers alike as well as to ensure law and order in the cattle market, $600 \mathrm{~m}^{2}$ will be sufficient for that purpose.

Cattle-housing facility - most of the cattle brought to this market come by trekking, and only few by truckage. A special place is needed to keep the livestock before the market day; this facility will serve as a waiting facility for the cattle and the caretakers before they are sold. The facility is expected to have shades and provision for heater during cold and wet seasons; it will have cabins for cattle caretakers so that they watch the animals. There will be two such facilities and will occupy an area of $5,000 \mathrm{~m}^{2}$.

Revenue post - the building will serve as a revenue collection point at the entrance of the cattle market. It will occupy $400 \mathrm{~m}^{2}$.

Parking spaces - if a market environment is to be orderly and free from traffic chaos, it must have enough parking lots or spaces. This cattle market is not an exception, as there are parking spaces for trucks/ trailers, pick-up vans and cars. They are separated to ensure orderliness and compatibility of parking. An area of $6, \mathrm{ooom}^{2}$ will be enough for this purpose.

Loading/off loading bay - this facility, as the name implies, is meant for loading of purchased cattle for movement down to the southern part of Nigeria. Animals brought for sale at the market by trucks/trailer or pick-up vans are off-loaded at this facility. There will be two of these facilities and will cover an area of 5,000 $\mathrm{m}^{2}$.

Shops and toilets - there will be three blocks of shops and each block will have ten shops and they will cover an area of $900 \mathrm{~m}^{2}$. The toilets on the other hand also have three blocks and three pit latrines are to be dug in each of the blocks; an area of $900 \mathrm{~m}^{2}$ will be sufficient for this purpose.

Small animals market - this is an area where small animals such as goats and sheep will be traded. It will cover an area of $2,900 \mathrm{~m}^{2}$.

Water boreholes - two water boreholes will be sufficient for the cattle and human water needs at the cattle market. It will be preferable if hand pump and electric powered borehole types are sunk.

Generator room - the market requires a generator set for power supply when there is power outage from the national grid; about $200 \mathrm{~m}^{2}$ will be enough for this purpose. The entire cattle market will have a wire fence round it except for the trucks and pick-up vans parking area.

Refuse dump - an area for the disposal of refuse that may be generated in and around the proposed cattle market is required. A site of $1,000 \mathrm{~m}^{2}$ will be sufficient for this purpose. The remaining land will be reserved for future development.

Project Funding. The three beneficiaries of the proceeds of the cattle market will fund the project; they are the Local Council of Mubi South, the Mubi Emirate Council and the Adamawa State Government. About $45 \%$ of the fund should come from the State Government, 35\% from the Local Government (Mubi South), and about 20\% from the Mubi Emirate Council.

Phasing. The project will consist of three phases. The first phase will be creation of access roads provided in the plan, followed by the provision of the utilities such as water supply, electricity and drainages. The final phase will be the construction of the facilities specified in the plan.

Implementation strategies. The implementation of the above stated new cattle market proposals needs monitoring and will be carried out in phases. Direct labour strategy shall be used so as to reduce cost of implementation through award of contracts, which most of the times lavishes money.

\section{CONCLUSION}

The paper examined the traffic situation in and around the Mubi cattle market by carrying out traffic volume count (survey) and parking survey to determine the number of vehicles passing certain cordon points and vehicles parked at designated locations in and around the cattle market to analyse the traffic situation and its implication on other land uses especially residential and other commercial land uses around the market. The high volume of traffic on the 3.5 metre unpaved road leading to the market on the market day coupled with the serious shortage of parking space(s) force some vehicles to park on the unpaved road in front of the market thereby causing a serious traffic bottleneck in and around the cattle market. The current location of the market does not give room for expansion and improvement of facilities to accommodate a functional cattle market with minimal planning problems, but the road junctions and general circulation can be developed to ease the situation. The implications of the spatial analysis of traffic and parking for urban development of Mubi cannot be overemphasized. The current cattle market can be converted into another use by the local council in wide consultation with the people (participatory planning). The relocation of the market has been suggested by the stakeholders in the cattle marketing business, as well as the residents of the surrounding area. The proposed design should be implemented for a desirable economic 
activity in the area. Urban growth and development towards the new cattle market cannot be controlled through policy framework for efficient cattle market and sustainable urban system.

\section{ACKNOWLEDGEMENTS}

The authors of this article wish to thank the Mubi cattle market authority for providing relevant information for the paper. All the cited authors are duly acknowledged in the references section.

\section{REFERENCES}

[1] Joshua, P. B. (2014), Cattle Economy in Mubi, Adamawa State, Nigeria, Proceedings of the $55^{\text {th }}$ Annual Conference of the Association of Nigerian Geographers (ANG) held in Abuja on April $19^{\text {th }}-27^{\text {th }}$ 2014, Ijere, J. A., Maryah, U. M. (eds.), University of Maiduguri: Geography Department, pp. 48-54.

[2] Mubi, A. A., Michika, S. A., Midau, A. (2013), Cattle Marketing in Mubi Area of Adamawa State, Nigeria, in Agriculture and Biology Journal of North America, Vol. 4(3), pp. 199-204.

[3] Slack, B. (2013), Methods in transport geography, in Rodriguez, J.P. (ed.), The Geography of Transport System, New York: Routledge.

[4] Kehinde, C. G. (1999), Basic principles and methods of Urban and Regional Planning, Lagos: Libro-Gem Books, pp. 53-79.

[5] MLCSL (2010), Livestock Markets in the $21^{\text {st }}$ Century: A Review of Livestock Markets in Englandthe Challenges and Opportunities, London: MLC Consulting services Ltd.

[6] White, J. T. (1999), General Factors in Market Planning and Design, in FAO Bulletin, Market Infrastructure Planning: A Guide for Decision Makers, Rome: FAO.

[7] Yerima, B. D., Birmah, J. P. (2015), Analysis of the Planning Implications of the Current Location of Mubi Cattle Market in Adamawa State-Nigeria, International Journal of Business and General Management, Vol. 4(1), pp. 13-18, 2015.

[8] *** TipTopGlobe.com, City of Mubi, Adamawa State, Nigeria, last accessed in 2015. Available online at: http://www.tiptopglobe.com/city?n=Mubi\&p=225721

[9] Lock, M. (1976), Mubi Master Plan.

[10] *** (2006), Mubi South Local Government Council Registry, Nigeria.

[11] Adebayo, A. A., Dayya, S. V. (2004), Ethnic Groups and Languages, in Adebayo, A. A. (ed.) Mubi
Region: A Geographical Synthesis, Yola; Paraclete Publishers, pp. 120-122.

[12] *** Transport Certification Australia Limited, (2008), Transport Regulatory Uses of Telematics in Europe, Vol. 1.

[13] Adeneke, S. (2003), Relocation of Markets in Nigerian Cities: A case study of Bida New Central Market”, Unpublished M.Sc. thesis in Urban and Regional Planning Department, Ahmadu Bello University, Zaria, pp. 1-29.

[14] Ndianaefo, M. (2016), Nigeria: Inside Maigatari Cattle Market, Daily Trust, $19^{\text {th }}$ July edition.

[15] Joshua, P. B. (2010), The Planning Implications of the Current Location of the Mubi Cattle Market, MURP thesis, Department of Urban and Regional Planning, Federal University of Technology, Yola, Nigeria.

[16] Khisty, C., Kyte, M. (1991), Lab and Field Manual for Transportation Engineering, Prentice Hall, Englewood Cliffs, NJ.

[17] *** Daily Guide (2014), Largest Cattle Market Commissioned, Available Online www.modernghana.com [Accessed June $9^{\text {th }}, 2018$ ].

[18] Bailey, D., Christopher, B. B., Peter, D. L. Francis., C. (1999), Livestock Markets and Risk Management among East African Pastoralists: A Review and Research Agenda, Economic Research Institute Study Papers, Paper 170, 1999. Available Online at: https://digitalcommons.usu.edu/en/170

[19] *** Planning Committee (2009), Proposed Construction of Replacement Livestock Market with Associated Car and Lorry Parking at Land Adjacent to Veldifer Cottages, Roman Road, Stretton Sugwas, Hereford", Available Online at: www.councilors. herefordshire.gov.uk/udp

[20] Africa Development Bank Group (ADBG), (2010), Regional Study on the Sustainable Livestock Development in the Greater Horn of Africa, Main Synthesis Report, vol. 1.

[21] *** (n.a.), Von Thunen's Model of Land Use, Available online at: www.sjsu.edu/faculty/watkins/ thunen.

[22] *** (2007), Sustainable Adamawa Development Report, Max Lock Consultancy Nigeria Ltd., Available online at: https://www.westminster.ac.uk/file/8356/ download?token=hOWJnUGX. 